\title{
LIBERICA COFFEE FARMERS GROUP COMMUNICATION PATTERN FOR SUPPORT OF SUKOREJO ECOTOURISM
}

\author{
Prima Mulyasari Agustini ${ }^{1 *}$, Eli J. Miharja ${ }^{2}$, dan Tuti Widiastuti ${ }^{3}$ \\ ${ }^{1,2,3}$ Universitas Bakrie, Jakarta, Indonesia. \\ *prima.agustini@bakrie.ac.id,
}

\begin{abstract}
Tanjung Jabung Barat which is a peatland with the main commodity production of Liberica Coffee, the area is being developed by oil and gas companies and governments into ecotourism destinations. Ecotourism development is considered to be able to improve the walfare of the community and also maintain the conservation value of the coffee ecosystem. Liberica Coffee farmers are empowered to support ecotourism. This paper aims to describe about: (1) Interaction between Liberica Coofee farmers and their interactions with the stakeholders, (2) A one-way and two-way communication hierarchy between farmers and the stakeholders, and (3) the mapping of communication networks between liberica coffee farmers and the stakeholders. This study was conducted using qualitative methods with interviews and FGD were conducted with Liberica Coffee farmers, the company and the local government. The conclusion of this paper indicate that: (1) coffee farmers carry out intensive and long duration communication conducted at the coffee beans processing site. (2). Communication generally takes two directions so there is a tendency for farmers to take action and move together without waiting for orders, and (3) Communication is carried out by the leader of the farmer group with the stakeholders also carrried out intensively and patterned so that it can support the development of the ecotourism in "Sukorejo" Liberica Coffee Village in a realtively short period of time.
\end{abstract}

Keywords: Farmer group communication patterns, Liberica Coffee, Ecotourism.

\begin{abstract}
Abstrak
Tanjung Jabung Barat yang merupakan wilayah gambut dengan produksi utama kopi liberika, sedang dikembangkan oleh perusahaan dan pemerintah menjadi destinasi ekowisata. Pengembangan ekowisata dianggap dapat meningkatkan kesejahteraan masyarakat dan juga menjaga nilai konservasi dari ekosistem kawasan kopi. Petani kopi Liberika berpotensi untuk mendukung ecotourism. Arikel ini bertujuan untuk mendeskripsikan mengenai (1) Interaksi antar petani kopi liberika dan interaksinya dengan stakeholder (2) hirarki komunikasi satu arah dan dua arah antar petani dan stakeholder, (3) memetakan jaringan komunikasi antar petani kopi liberika dan stakeholder. Kajian ini dilakukan dengan metode kualitatif dimana dilakukan wawancara dan FGD dengan petani kopi liberika pihak perusahaan dan pemerintah setempat. Simpulan artikel ini mengindikasikan bahwa: (1) para petani kopi melakukan komunikasi yang intensif dan lama, yang dilakukan di tempat pengolahan bijih kopi. (2). Komunikasi umumnya berlangsung dua arah, sehingga ada kecenderungan petani bergerak bersama tanpa menunggu perintah, (3) Komunikasi yang dilakukan pemimpin kelompok petani dengan stakeholder juga dilakukan dengan intensif dan terpola sehingga dapat mendukung pengembangan ekowisata kampung kopi liberika "Sukorejo" dalam waktu yang relatif singkat.
\end{abstract}

Kata Kunci: pola komunikasi kelompok petani, kopi liberika, ekowisata.

\section{INTRODUCTION}

Starting in 2017 numbers of oil and gas company operating in Tanjung Jabung Barat work closely with the local government to actively promote the tourism sector especially ecotourism in effort to increase the regional income. Ecotourism was selected as the main development of the region because it is considered has an added value which is the preservation of the ecosystem and also 
Tanjung Jabung Barat has a large potential to be a tourist destination. One the example of a pilot project in the development of ecotourism is the development of a tourism village, the liberika coffee village. Located in Mekar Jaya Village, Betara, Tanjung Jabung Barat, this village has a distinctive commodity, namely the liberika coffee tungkal composite. The development of the liberika coffee village as an ecotourism destination is supported by the the local coffee farmer. To make sure the interaction cohesiveness, the intensity and the communication patterns of the coffee farmer which are involved must be analyzed.

The distinct commodity of the local community, the liberika Coffee tungkal composite, has a unique taste, it taste somewhere between Robusta and Arabica types. this type of coffee can be found in the regions of Jambi and Bengkulu. In Jambi, the producer of liberika coffee is concentrated in In Betara District, Tanjung jabung barat, in the area there are around 2700 hectares which is all planted with liberika coffee plantations. The processed product of the liberika coffee plantations are the main source of income for the locals.

SKK Migas and the other oil and gas companies operating in Tanjung Jabung Barat, has initiated the development of a new ecotourism destinations in the region, the development named Kampung Kopi Liberika "Sukorejo" which is located in Mekar Jaya Village, Betara District, Tanjung Jabung Barat. The main purpose is the empowerment of local communities and maintain the sustainability of peat and the liberika coffee ecosystems, while providing a new tourism destinations. This is inline with the Moscardo research. Ecotourism developments also imply to smaller and more specialist forms of accomodation. Ecotourist accomodation is intended to be located in wilderness areas, and they tend to be smaller and locally owned, providing local employment and being spread over a wide area rather than clusters in one resort (Moscardo, et all in Duffy, 2002: 66) . The difficulties associated with conventional tourism are definitely apply to ecotourism, because it forms one part of a global tourism business, and also one of the growing sectors of the tourism industry (Cater in Duffy, 2002: 66). However, ecotourism is one of the best a strategy of economic development that not only minimize the negative effect to the environment but also preserve the nature.

The careful and well thought development of the region as an ecotourism destination is expected to drive the community's economy while preserving the environment. Empowerment of the liberika coffee tungkal composite becomes an idealism of its own. The educational function of the ecotourism has become an important role, ideally tourists able to understand the making process of the liberika coffee tungkal composite from the first till the final process, from the sightseeing of the coffee plantations, coffee ore processing, packaging, and finally served with a variety of variations. Tourists will start and end the ecotourism journey in the UKM Gallery which provides the liberika coffee that can be enjoyed immediately.

One of the farmer group that produce high quality liberica coffee is the Sido Muncul Farmer Group. They are the leading group of the pilot project, in the first year they will receive the assistance from an implementing partner of SKK Migas PetroChina International Jabung Ltd. CSR activities. The asistance will provide help for the farmer group starting from pre-harvest to post-harvest activities. The empowerment of the liberika coffee farmer is intended to support the Sukorejo ecotourism development, in addition to increase the production and quality of coffee produce.

Communication that occurs in the Sido Muncul Farmer Group appears in line with the Communication Convergence Model (West \& Turner, 2017 and Suhartini, 2017:284). In the Communication Convergence Model there is the term interactive communication. The main goal of This interactive communication include many principles, such as: (1) information, 
(2) dialogue, (3) negotiation, (4) mutual understanding and mutual understanding, (5) joint action (social action), and (6) symmetrical social relations. Convergent communication is carried out continuously through a network and is based on the rules of collectivity to obtain mutual understanding in social reality.

Communication in Sido Muncul Farmer Group is identified as a small group communication. According to Turner \& West (2017) some small groups are very cohesive, which has a high level of togetherness and strong ties. Cohesiveness will influence the group to function effectively and efficiently. The benefits gained from small groups with the exchange of viewpoints are called synergy. Synergy is the process by which point of view can be given in dealing with a problem or event.

Network formation and role behavior are two important components of small group behavior. Networks are communication patterns where information is channeled (Turner \& West, 2017). Networking communication is also seen as a formalized structure created by groups as a means of group communication. In small groups where the are only a few resources, communication patterns which combining several communication network structures will be developed., this communication network is a general communication system that will be used by groups in sending messages from one person to another. Group communication in farmer groups occurs knowledge sharing. Knowledge sharing is a social interaction that involves knowledge, experience and skills between individuals in a group, it is meant to improve their competence

Sido Muncul Farmer Group can be said as a leading producer of liberika coffee product. Coffee ore processing with the best quality has become the main standard in producing coffee ores which have begun to be favored by various coffee outlets in Jambi and surrounding areas. Because of the high standard, Mekar Jaya Village is regararded as the main spot of the ecotourism area of the liberika coffee village
"Sukorejo".

Cohesiveness in the farmer groups is very important (Handaka \& Surokim (2014) Groups with high cohesiveness will be easier to achieve good production quality, as the result it will increase the income of the farmers. A cohesive farmer group will also support the development of liberika coffee ecotourism, in Tanjung Jabung Barat. Communication pattern in Sido Muncul Farmer Group important for this research (Ekasari, et all, 2013; Mulyandari, et al, 2010; Tesfaye, 2010; Widiastuti, et.al, 2019; Mahatir et.al, 2015, and Saputra et.al (2012). Therefore, this paper presents the following aspects: (1) Interaction between liberika coffee farmers and the stakeholders, (2) a one-way and two-way communication hierarchy between farmers and stakeholders and (3) mapping the communication networks between the farmers liberika and the stakeholder

\section{METHODOLOGY}

This research uses qualitative method with a case study approach. According to Creswell \& Cresswell (2017: 8) and Dezin \& Lincol (2018), qualitative design is a design that does not have fixed rules and procedures, but is more open and constantly developing. Case studies are research strategies in which researchers carefully investigate a program, event, activity, process or group of individuals. Cases are limited by time and activity, and researchers gather complete information using various data collection procedures based on a predetermined time. The technique in this qualitative research is a single case study. According to Robert K. Yin (2014), case studies are used as a comprehensive explanation that deals with various aspects of a person, a group, an organization, a program, a social situation that is researched, pursued and explored as deeply as possible.

Data Collection which carried out in-depth interviews and focus group discussions with sido muncul farmer group liberika coffee farmers, the head of Corporate Social Responsibility 
Department of PetroChina Jabung Ltd., and Local government, such as head of Resional Infrastrucutre, Bappeda Tanjung Jabung and Head of Mekar Jaya Village, and Head of Tourism Conciuous Group.

The object of this research is the communication patterns of the Sido Muncul coffee farmer group in order to support the Sukorejo ecotourism. Research subjects are the liberika coffee farmers, the oil and gas company and the local government. Data validity is done by triangulating informants. Data analysis is done by observing social phenomenon, identifying and re-checking the data obtained, then categorizing information, explaining the categorization relationship in order to obtain a conclusions. This research is scientific and academic without involving any practical interests.

\section{RESULT AND DISCUSSION}

\section{Interaction Between Liberica Coffee Farmers and The Stakeholders.}

The interaction carried out by the coffee farmers members of the Sido Muncul Farmer Group, both between fellow farmers in one of the group and with other farmer groups. There are six active groups of liberika coffee farmers in Betara District. In addition, the head of the farmer group becomes a bridge in communicating the interests of various parties to the farmer group he leads.

The group leader interacts intensively with the stakeholders from the government, both at the local and regency level. Extension communication channel important for interaction between member of farmer group and stakeholders (Okwu, et.all, 2011 an Mihardja et.al, 2019).The head of the Sido Muncul farmer group also communicates various needs and interests of the group to be coordinated with various offices related to coffee commodity development. For the needs of ecotourism in Tanjung Jabung Barat, the head of the farmer group interacts with the implementing partner and tourism-conscious group (Pokdarwis) through members of the Sido Muncul farmer group who are administrators of the Pokdarwis.

Interactions that occur among members of farmer groups, occur in a variety of activities carried out at the Sido Muncul Cooperative area, including: making of the management accountability report, which will be reported at the Annual Member Meeting, arranging permission to establish a cooperative, identifying the need for administrative equipment, such as computers and printers, and adding coffee business units.

Interactionalsotookplaceintheimprovement activities of liberika coffee cultivation, where KPSM (Kelompok Tani Sido Muncul/Sido Muncul Farmers Group) carried out the following activities, such as: preparation of coffee storage sheds, provision of post-harvest coffee processing machines, procurement of Pulper, Huller and Sorting machine for dry coffee beans, breeding of Trichoderma Conii fungus in Hayati Agent House, to eradicate white Root Fungus, which considered as a pests, and making of biopesticides, an organic solid fertilizers and liquid fertilizers.

Coffee farmer interaction also occurs with the implementing partner and other farmers in training activities organized by the implementing partner of PetroChina. The main goal of the training is to improve farmers' knowledge and skills, with the implementing partner and the coffee entrepreneurs. The training activity is aiming to change the way of thinking, the paradigm and improve the understanding and skills of coffee processing, so that high-quality coffee products can be produced.

Assistance is carried out by the implementing partner in collaboration with the CSR section of Petro China Jabung. KPSM was very enthusiastic in participating in the training. Coffee farmers carry out intensive and prolonged communication, which takes place at the coffee ore processing plant. Usually 
this learning session lasts until midnight. The leader of the sido muncul farmer group seen as an open minded and resourceful person, so the group member (farmers) have their willingness to cooperate. The female in the village of Mekar jaya often provide support and also involved in the learning process.

The results from the enthusiasm of KPSM farmers in improving and increasing knowledge and skills of cultivation are a significant reduction in white fungus attacks and higher quality coffee products, even reducing production costs.

\section{One-Way and Two-Way Communication Hierarchy Between Farmers and The Stakeholders}

Communication carried out by farmers of KPSM is carried out intensively, so that they can work together and develop group cohesiveness. Group members are involved in a participatory manner, as well as involving the government and its technical elements. The active participation of farmers and their wives in Mekar Jaya Village has enabled farmers to increase both quality and quantity of liberika coffee. Communication generally takes place in two directions, so there is a tendency for farmers to take an action without waiting for orders. However, for the need to complete

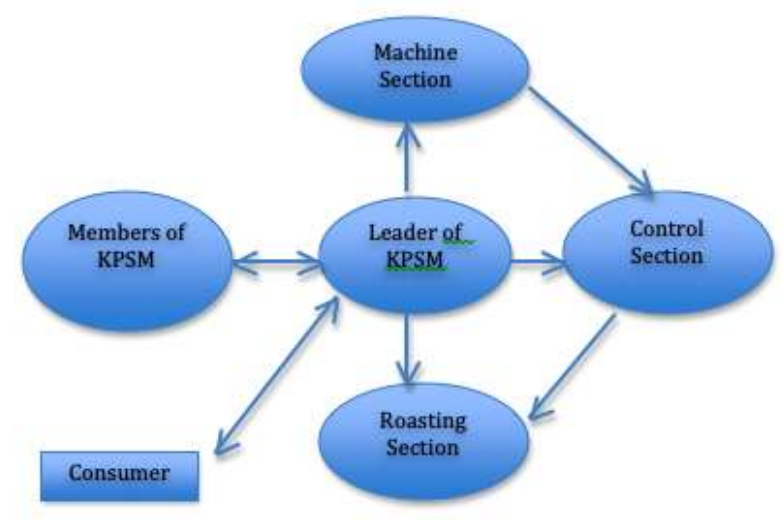

Figure 1.

A One-Way and Two-Way Communication Hierarchy Between Coffee Farmers and The Stakeholders the processing of coffee ore from upstream to packaging, and submitted to the buyer, it requires harmonization of activities steps or Standard Operational Procedure that requires one-way communication instructed by leader of the farmer group (illustrated in Figure 1).

With convergent communication techniques that combine one-way and twoway communication, makes the farmers have a solid work team (Aminah, et all, 2014). The coffee product produced of the KPSM has improved to be a high quality coffee products, so that it has an implications for the improved coffee prices. Farmers are starting to get passionate about returning to agricultural activity and replanting in order to replace the already dead coffee plantation, Farmers benefit economically. The tungkal composite liberika coffee is increasingly known along with its increasingly broad marketing.

\section{The Mapping of Communication Networks Between Liberika Coffee Farmers and The Stakeholders}

In order to produce high quality liberika coffee, it requires commitment from the farmers to follow and apply the results of the training in their liberika coffee plantations. The commitment of the farmers of the KPSM resulting in a premium quality liberika green bean.

The distribution of roles is as follows, there are 42 farmers which act as the upstream actors who prepare green beans which are processed according to coffee processing standards. The role of Petro China implementing partners is to oversee the cupping test process and help farmers to find markets. The coffee brand agreement produced by KPSM is Liberco which is short for Liberika Betara Coffee (illustrated in Figure 2).

The work team of KPSM consists of 8 people, with the division of work as follows such as: control section of 2 person, engineers as many as 4 people, and 2 parts of the roaster. 


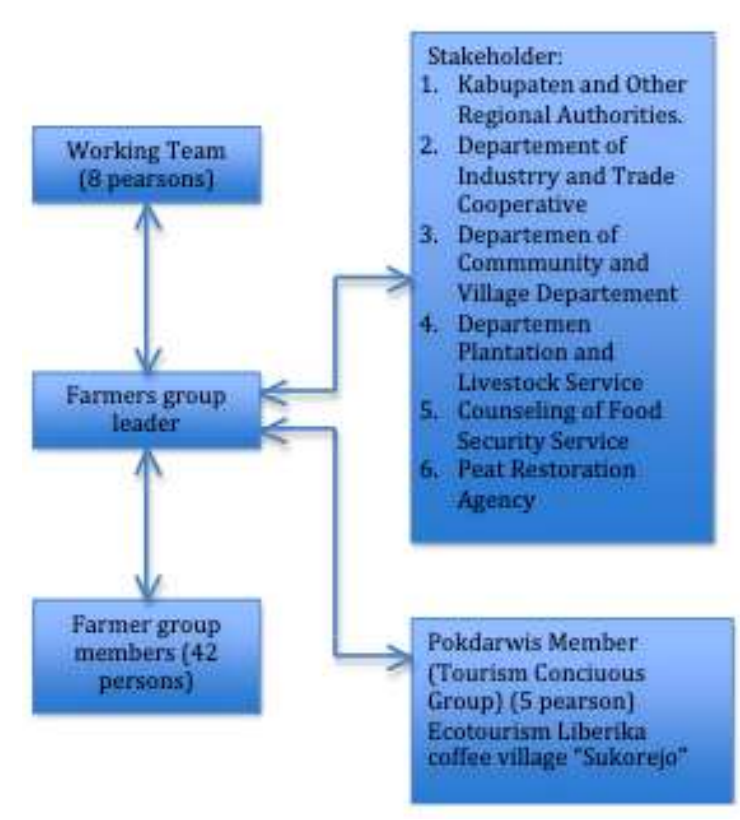

Figure 2.

The Mapping of Communication Networks Between Coffee Farmers and The Stakeholders.

KPSM is driven by one group leader, whose task is to manage and coordinate with the work team and the farmers who are members of the farmer group, with the total of 42 people. Each farmer has a 2 hectare land, where currently the productive area reaches 55.5 ha. In addition, the group leader conducts intensive communication with the stakeholders who come from the government service/depatement or the local government. The stakeholders who have done an intensive coordination and communication with KPSM are as follows: Regency and local government, Department of Industry, Trade, Cooperatives, and SMEs, Community and Village Empowerment Agency, Plantation and Animal Husbandry Service, Extension Service Department of Food Security, and Peat Restoration Agency (Illustrated in Figure 2).

InKPSM, communication whichis carried out with the tourism awareness group (Pokdarwis) in the series of ecotourism for the liberal coffee "Sukorejo" was carried out by 5 other people besides the group leader and the KPSM work team. Communication and coordination with the PetroChina Jabung company is mostly done through the implementing partners.
The exchange of information related to coffee ore processing continues and is patterned. Communication carried out by farmer group leaders and stakeholders is also carried out intensively and patterned so that it can support the development of the ecotourism of the liberika coffee village "Sukorejo" in a relatively short time.

\section{Discussion}

\section{Multi-Way Interaction in the Sido Muncul Farmers Group}

Interactions that occur in communication within the Sido Muncul farmer groups and their stakeholders are in line with the convergence communication model. Communication that takes place in a multi-directional direction between recipients towards a focus or interest that is shared. Communication takes place dynamically and develops towards collective understanding. Communication that takes place in a multi-directional direction between recipients towards a focus or interest that is shared. The principles that exist in the Sido muncul farmer group communication with the stakeholder is informative communication, takes place dialogically, there is negotiation between parties, mutual understanding and building mutual understanding, and there are joint actions to achieve the goals expected by farmers, companies and government groups Tanjung Jabung Barat Regency.

The multi-directional interaction of the Sido Muncul farmer group also formed a communication network. The network is a social structure created by communication between individuals and groups ((Littlejohn \& Foss, 2017). The Sido Muncul Coffee Farmer communication network is a channel used to forward messages from one farmer to another. then a communication pattern will be developed that combines several communication network structures, this communication network is a general communication system that will be used by the Sido Muncul coffee farmers group in sending messages from one farmer 
to another farmer or to other stakeholders. The communication network is also seen as a formalized structure created by the Sido Muncul coffee farmers group as a means of communication of coffee farmer groups. In the network analysis, the link between each farmer and other farmers in the process of communicating with dyads and triads is important, each farmer and stakeholder also meets a variety of services in the communication network. The Communication Pattern of Farmer Groups is also accordance to the research on Communication Patterns in Agricultural Human and Social Capital Development, conducted by Mulyandari, et al, 2010. The results of this study indicate that communication patterns in increasing the capacity of agricultural human resources in the concept of human and social capital superior refers to the convergent interactional communication patterns through various knowledge models.

In the interaction between members of coffee farmers, counseling is also carried out by the company. The communication pattern in this counseling is also linear, but the communication of learning is convergent or participatory with the establishment of a liberika coffee field school. This pattern is accordance to research about Communication Pattern and Conflict in Agricultural Extension by Ekasari, Z. Kartika, et al, 2013. The result of this research indicate of communication in social engineeringbased extension is a linier pattern (top down), while communication in social learning-based extension is using a convergent (participatory) pattern. The research suggest that social learning-based extension should be developed as a potential way to sustain an important role of extension in agricultural and rural development

In the interaction of farmers and stakeholders, each coffee farmer has an important role in their communication network. As explained in network theory (Littlejohn \& Foss, 2017), the role of farmers in the group is as a bridge, where members of the coffee farmers group are also members of other groups such as Pokdarwis.
There are also farmers who act as "degrees", where farmers who connect other farmers in their groups with other farmers who are not in their group. The aim is to cooperate and broaden the network. Not all farmer group members have many links, only a few people have a wide network, both with fellow farmers, or links to local governments and companies. The communication network seems to be starting to work on the Sido Muncul coffee farmer groups, this is indicated by the existence of farmers who regulate the flow of information within the group and vice versa, as well as between group members, the existence of the farmer group farmer groups uniting all coffee farmers with the interests of supporting ecotourism and liberaka coffee production, there is an influence that is transmitted by coffee farmers to other coffee farming communities, even to Tanjung Jabung Timur (neighboring regency), and in groups of farmers there are often talks and apprenticeships: in the context of exchanging farmer group resources. Referring to the opinion of De Vito (2017), the structure of the Farmers group communication network tends to have a wheel structure, where the leader of the coffee farmers group is clear. The leader position is at the center. The leader is the person who can send and receive messages from all members. If a member communicates with other members, then his message must be conveyed through other leaders.

\section{Knowledge Sharing as Key to Success in Sido Muncul Farmers Group Cohesiveness .}

Knowledge sharing is a group activity of Sido Muncul coffee farmers which is carried out to improve knowledge and skills. Knowledge sharing is a social interaction (Littlejohn \& Foss, 2010) that involves knowledge, experience and skills between coffee farmers in groups to improve their competence. Knowledge sharing is useful for creating new knowledge, so that it can produce innovation, improve the skills of each coffee farmer group member and reduce the risk of repetition of the same mistakes. In 
the implementation of knowledge sharing, coffee farmers group members are expected not to save their own knowledge which is feared will lead to unfair competition. The usual approach to motivate knowledge sharing carried out by coffee farmers is in line with what was stated by Brčić \& Mihelič, (2015), namely: Supervise control, where the Sido Mucul coffee farmer group makes formal rules for its members to conduct knowledge sharing activities. Activities are usually carried out once a week at the farmer's meeting hall. Group members are usually motivated by other group members, because there is a belief that other members will contribute the same. So there was a social exchange in this coffee farmers group. In addition, appreciation is given to members who do knowledge sharing, for example: being introduced to eco-tourism guests as "important" people in developing liberal coffee in the Tanjung Jabung barat area.

Knowledge sharing is not just a matter of coffee, but also about other issues. The aim is to maintain group cohesiveness, where members are expected to be interdependent. In addition to increasing coffee production, the target for liberika Sido Muncul coffee farmer is also maintaining coffee quality, so that marketing is expected to continue to increase. The development of Sukorejo liberika coffee ecotourism area has become a hot topic later on coffee farmers. This is because Sido Muncul coffee production area has become one of the important spots in the ecotourism. Farmers and other stakeholders are given a place to share information, so farmers prepare themselves and make interesting spots so that they can fully support the ecotourism of Sukorejo Lieberika coffee village which has become a new tourism icon in Tanjung Jabung Barat.

In conducting knowledge sharing activities, communication networks are also built based on friendship patterns between farmers, who are adapted to the characteristics of the farmer's social environment, and there is a pattern of learning among members of the coffee farmers group. This is accordance to the research about Interpersonal Communication pattern of famers through key communicators regarding some selected Gram Panchayat Activities by Goswami and Sarkar, 2009. The result of this research indicate key communicator network of farmers was studied as neighbourhood, friendship and dicussion group pattern to explore farmer's interpersonal communication pattern regarding Panchayati Raj Insitution activities. Neighbourhood pattern of interaction show leaset dense key communicator network and least dependence of them for seeking information. Friendship group pattern of interaction features higher number of respondents seeking information from more than one key communicator. Discussion group pattern of interaction shows least number of key communicators and highest inter-key communicator interaction.

Thus, besides bringing up the roles of farmers, knowledge sharing conducted by Sido Muncul coffee farmers, reveal the domination from farmers who are considered to have more knowledge about coffee cultivation, processing and the ecotourism of liberica coffee, which is shared with farmers and other stakeholders in the communication network chain. By maintaining an open and shared communication pattern, the cohesiveness of the Sido muncul coffee farmers group become strong, so that it can support the ecotourism of Sukorejo liberika coffee which has become a tourism icon of Tanjung Jabung Barat.

\section{CONCLUSION}

The result of this study indicates that coffee farmers carry out intensive and long duration of communication that is conducted at the coffee beans processing site. The community leader is seen as a person of openness, so that the farmers have the willingness to cooperate. Communication generally takes two directions so there is a tendency for farmers to taking action without waiting for orders, . The exchange of information related to coffee 
beans processing is continuing and is patterned. Communication is carried out by the leader of the farmer group with the stakeholders also carrried out intensively and patterned so that it can support the development of the ecotourism in "Sukorejo" Liberica Coffee Village in carried out in a relatively short period of time.

\section{ACKNOWLEDGEMENT}

The study was funded by the Ministry of Research and Universities thorough the Higher Education Primary Research Scheme in 2019.

\section{REFERENCES}

Aminah, S., Sumardjo, Lubia, D. and Susanto, D. (2014). Perubahan Model Komunikasi dan Pergeseran Paradigma Pembangunan dalam Perspektif Sejarah. Jurnal Paramita, 24 (1), 92103. [ISSN:0854-0039]

Brčić, Ž. J., \& Mihelič, K. K. (2015). Knowledge Sharing Between Different Generations of Employees: an Example from Slovenia. Economic ResearchEkonomska Istraživanja, 28(1), 853867

Creswell, J. W., and J. David Creswell. (2018). Research Design-Qualitative, Quantitative, Mixed Methods; 5 th Edition. Sage Publication.

DeVito, J. A. (2017). Human Communication Book - The Basic Course; 14 th edition. Pearson.

DeVito, J.. A. (2018). The Interpersonal Communication Book; 15 th edition. Pearson.

Denzin, N. K. And Lincoln, Y. S. (Ed.) (2018). Handbook of Qualitative Research. Sage Publication.

Ekasari, K., et.al. (2013). Communication Pattern and Conflict in Agricultural Extension. Asian Sociael Science, 9 (5), 27-33.

Duffy, R.. (2002). A Ttrip Too Far: Ecotourism,
Politics and Exploitation. Earthscan Publications Ltd.

Fennell, D. A. (2002). Ecotourism Programme Planning. CABI Publishing.

Handaka, T. and Surokim. (2014). Pola Komunikasi Kelompok Petani Tembakau Madura sebagai Basis Penyusunan Kebijakan Pemberdayaan Ekonomi Politik. Jurnal Karsa, 23 (2), 38-48.

Littlejohn, S. W., and Karen. A. (2010). Foss. Theories of Human Communication. Waveland Press, Inc.

Mahatir, M. (2015). Pola Komunikasi Komunitas Laskar Sepeda Tua Pekanbaru Dalam Mempertahankan Solidaritas Kelompok. JOM FISIP, 2 (2), 1-12.

Mihardja, Eli., B.P.L.Bintoro, D. M. Purtanti, R.Widiastuti, P. M. Agustini, and F. Adriati. (2019) Narration of Develpoment of Ecotourism in Instagram for City Branding, Study in Pinrang Regency. International Journal of Arts and Social Science, 2 (4), ISSN: 2581-7922.

Mulyandari, R. S. Hartati, Sumardjo, N. K. Pandjaitan, dan D. P. Lubis. (2010). Communication Patterns in the Development of Agricultural Human and Social Capital. Forum Penelitian Agro Ekonomi, 28 (2), 135-158.

Okwu, O. J., \& Daudu, S. (2011). Extension Communication Channels' Usage and Preference by Farmers in Benue State, Nigeria. Journal of Agricultural Extension and Rural Development, 3(5), 88-94.

Rupak, G. and A. Sarkar. (2009.) Interpersonal communication pattern of farmers through key communicators regarding some selected Gram Panchayat Activites. MPR Paper No. 25983, posted 23 Oct 20120 UTC, http://mpra. ub.uni-muechen.de/25983/ 
Saputra, A. O. (2012). Memahami Pola Komunikasi Kelompok Antar Anggota Komunitas Punk di Semarang. Jurnal The Messenger, 4(1), 25-37.

Suhartini, R. (2017). Model Komunikasi Konvergensi untuk Perubahan Sosial: Studi Interaksi Warga Kampung dan Kmapus IUNSA. Jurnal Komunikasi Islam, 07 (02), ISBN 2088-6314, DOI: $\quad$ http://dx.doi.org/10.15642/ jki.2017.7.2.281-296.

Tesfaye, T., \& Karippai, R. S. (2010). Farmers Training Effectiveness in Terms of Changes in Knowledge and Attitude: The case of Holeta, Melkassa and Debre zeit Agricultural Research Centres,
Ethiopia. Journal of Agricultural Extension and Rural Development, 2(5), 89-96.

Turner, L. H. And R. West. (2017). Introducing Communication Theory: Analysis and Aplication. McGraw-Hill.

Widiastuti, T., E. Mihardja, and P. Agustini. (2019).Women's Participation on Tourism Village's Management in the Dieng Pandawa Tourism Awareness Group, 3 (1) https://doi.org/10.7454/ ajce.v3i1.175

Yin, R. K. (2013). Case Study Research: Design and Methods-Applied Social Research Methods. Fifth Edition. Sage Publication. 